$\begin{gathered}\text { ADVANCE RESEARCH JOURNAL OF SOCIAL SCIENCE } \\ \text { Volume 11 | Issue 2 | December, 2020 | 73-79 } \\ \text { REVIEW }\end{gathered}$
ISSN-0976-5611
DOI: 10.15740/HAS/ARJSS/11.2/73-79

\title{
Action Research in Social Science
}

Loveleen Kaur*, Kanwaljit Kaur and Sukhdeep Kaur

Department of Extension Education and Communication Management, Punjab Agricultural University, Ludhiana (Punjab) India (Email: loveleen_kaur77@yahoo.in)

\section{ARTICLE INFO :}

Received

Accepted

: 30.08 .2020

: 17.10 .2020

\section{KEY WORDS :}

Action research, Social science

HOW TO CITE THIS ARTICLE :

Kaur, Loveleen, Kaur, Kanwaljit and Kaur, Sukhdeep (2020). Action Research in Social Science. Adv. Res. J. Soc. Sci., 11 (2): 73-79, DOI: 10.15740/HAS/ARJSS/ 11.2/73-79.Copyright@2020:Hind AgriHorticultural Society

\begin{abstract}
Action research is the philosophy and methodology of research generally applied in social science. As people are the central concern in social sciences and it becomes the duty of the social scientist to involve oneself with contemporary problems of people for improving their situation. Action research is a type of social science research that that aimsat creating a desirable change in the situation as a result of planned action intervention. It is carried out to identify areas of concern, develop and test alternatives, and experiment with new approaches.By conducting action research, researchers are able to make changes in order to improve the settings in which they conducted research, rather than just gathering data and formulating theories, as in conventional research. Considering the significance of action research in social science, it becomes important to have a comprehensive knowledge of it. Thus, the present paper has been prepared with the objective to review and explain the concept of action research in social sciences.
\end{abstract}

